\title{
LIVELIHOOD STRATEGIES AND INCOME GENERATING OPPORTUNITIES: A CASE STUDY ON RURAL POOR HOUSEHOLDS IN KEDAH, MALAYSIA
}

\author{
Kalthum Hassan* \\ Universiti Utara Malaysia \\ Rohana Yusof \\ Universiti Utara Malaysia \\ Norehan Abdullah \\ Universiti Utara Malaysia
}

\begin{abstract}
The objectives of this paper are to uncover the livelihood strategies of the poor households in managing their incomes to sustain the household members' welfare and whether the strategies can be translated as opportunities for poverty alleviation. Adopting qualitative data collection method, an in-depth interview method is used to retrieve information on the expenditure pattern of the households and the underlying reasons for doing so. Five households with various demographic backgrounds are chosen from Mukim Laka Temin, Kubang Pasu District. This study discovers the expenditure of each poor household is managed by a woman and each household has its own unique livelihood strategies which are based on the type of jobs of the household members and the households' spending arrangements. All households prioritize their expenditure, food as the main priority, followed utility bills, transportation, education and others. Most households constantly receive financial supports from various sources such as government agencies and individuals in terms of zakat and donation. The study suggests the livelihoods strategies adopted by the households can be translated into opportunities for the poor households to improve their socio-economic status if the members receive proper provision of trainings and capitals.
\end{abstract}

Keywords: Household Expenditure; Livelihood Strategies; Poor Households.

\section{INTRODUCTION}

"The poverty of a household is related to its resource endowments, its organisational capacity to manage and deploy its resources, its labour force position, the available coping mechanisms and external or family contingencies which affect it" (Shahadat Hossain, 2005: 1).

\footnotetext{
* Corresponding author: Kalthum Hassan, School of Government, Universiti Utara Malaysia, 06010, Sintok, Kedah, Malaysia.+604-9287780. Email: kalthum@uum.edu.my.
} 
Basically poverty is defined and measured based on several attributes such as low income, insecurity and deprivation (Hossain, 2005 and Oluwatayo, 2009). Income measurement as poverty indicator is the most common practice in most countries. This is because it can be easily measured quantitatively and most countries use poverty line income as a measurement to determine extent of poverty of the countries. Therefore this study is focusing on the livelihoods strategies of household expenditure which is related to household incomes.

Managing a household's expenditure with very limited income is very challenging. This challenge is been facing by many poor households around the world. Generally, women are given the task to manage households' incomes and expenditures because they have the skills to plan and manage households' incomes efficiently. In most poor households, women are the key actors in determining the livelihood strategies of the households to sustain the households' welfare. To sustain food consumption and other expenditure of a poor household, a woman needs to carefully budget the household incomes so that the incomes able to cover at least the basic needs of the household members. This is very vital to ensure the continuity of the income generating activities by the household members. For example, if one of the members is not well enough to work for a week, it will affect the welfare of other household members because the less income generated at that period of time.

This study is to investigate the art of planning and managing households' expenditures among women of poor households. The objective of this paper is to uncover the livelihood strategies of the poor households in managing their incomes to sustain the household members' welfare. This study is also to discover whether the strategies adopted by the households can be translated as opportunities for poverty alleviation. This study will not determine the specific percentage or amount of money spent for the goods and services but to investigate the decision behind the allocation of monthly household budget and how the budget allocations and expenditures are prioritized.

This paper will start with discussions on background of poor households and their livelihood strategies to sustain their households' expenditure. This will include theories of poverty, poor household expenditure pattern and its contributing factors. Next is the discussion on methodologies and analysis on findings.

\section{LITERATURE REVIEW}

A household can be defined as a group of people who are living in a house, sharing the space for eating, sleeping and doing other housework. The household members share their incomes to cover the household's expenditure. For poor households, the incomes generated in the household are unable to cover the minimum level of basic needs to sustain the wellbeing of the household members (Department of Census and Statistics, 
2008). Rural economic activities are often in general have been related to agricultural activities. However, in reality in most part of rural areas in developing countries, the rural economy is diversified. For the poor rural households the incomes of the households are from combining incomes of each household member which are mostly from non-farm work. (World Development Indicators, 2008 and Oluwatayo, 2009). This approach offers poor rural households option for coping with crisis and enhances consumption and also ease the burden of household's head to sustain the household's basic needs (Oluwatayo, 2009).

Most of the poor households spend their incomes to fulfill their households' basic needs. Most studies find that a large portion of poor households' incomes is spent on food and shelter, and very small portion of poor households' incomes is spent on clothing, medicine, education and other necessities (Hossain, 2005).

Therefore, in order to survive and sustain, poor households adopt various strategies to diversify their incomes. This can stabilize their income and increase their purchasing power all year round. However, due to limited skills and capitals, poor households are compelled to strategies which enable them to survive but not to improve their welfare in the long run (Hossain, 2005).

A study by Jaiyebo (2003) in Nigeria demonstrates that most women choose supplementary occupations to sustain the households' basic needs. The study also finds the most preferred supplementary occupation is trading activity such as sale of snacks, soft drinks, fried bean balls and so on (ibid). This is because they find that trading is convenient to ensure they have cash in hand most of the times.

The trend of livelihoods strategies adopted and adapted by poor rural households should be the basis for formulation of effective poverty alleviation policy. This means that the policy is composed with the awareness of the economic and social milieu of the poor households. This has been elaborated by Ellis $(1999$, p.2) as follows:

"Future rural poverty reduction policies need to be better informed on the nature of these interactions. For example, it is fairly well known that the poor diversify in less advantageous labour markets than the better-off, i.e. in casual, part-time and unskilled work compared to full-time work or substantive self-employment. These findings are related to the asset status of the poor (e.g. low human capital) and barriers to entry resulting from low assets (need for skills, ability to navigate bureaucratic hurdles, etc.). It is possible that facilitating the poor to gain better access to opportunities (or to create their own opportunities) may turn out to be substantially more cost effective for poverty reduction than attempting, artificially, to support particular sectors or sub-sectors of rural economic activity."

The basic needs approach acknowledges the importance of basic needs. The objective of the approach is to ensure that the poor can have access to a minimum level of 
consumption of certain basic goods and services (Streeten, 1981; Peet \& Hartwick, 1999; Lewis, 1981). It suggests that a particular government or authority should provide a certain level of services and facilities to improve the income, health, nutrition level and housing condition of the poor (Drakakis-Smith, 1990; Streeten, 1981; Mabogunje, 1980). Through the services and facilities, a country can maintain and create a healthy and productive population that in the long run can help to increase productivity and promote growth in the country (ibid). It is vital to keep in mind that one society may have a different set of basic needs from another society. Furthermore, one household may have a different set of basic needs than the others.

The above discussions have deduced that livelihood strategies adopted by poor households to sustain their basic needs are in the less advantageous labour market. They work as casual, part-time and unskilled workers. Some of them involve in petty trading which can generate very little incomes. Their main objective to adopt the strategies is to survive but not to improve their socio-economic status in the long run due to lacked of skills and capitals and low educational background. Basic needs approach acknowledges the importance of poor households to have access to minimum level of consumption of certain basic goods and facilities. This can create a healthy and productive population. Therefore, household members can perform better at workplace if their basic needs are fulfilled. It is suggested by Ellis (1999); the poor may be able to change their socioeconomic status if they are given the access to capitals and skill trainings to enhance their existing income generating activities.

Therefore, besides investigating the strategies of the poor households to sustain their household basic needs, this study is also aimed to identify the economic activities (livelihoods strategies) that have been ventured by the respondents that can be translated to better income generating activities if they have access to capitals and proper trainings. This finding will suggest an alternative poverty alleviation approach that provides opportunities for the poor to improve their socio-economic status based on their livelihoods strategies to sustain their basic needs.

\section{RESEARCH METHODS}

The research questions and research objectives are:

\subsection{Research Questions}

1. How do poor households manage their expenditure to sustain the households' basic needs?

2. What are the poor households' strategies to ensure enough earnings to sustain the households' expenditure? 


\subsection{Research Objectives}

1. To analyse poor households' expenditure management approaches to sustain their basic needs?

2. To discover the poor households' strategies to ensure enough earnings to sustain the households' expenditure?

\subsection{Data Collection Method}

This study adopts qualitative data collection method and analysis. An in-depth interview method is used to retrieve information on the expenditure pattern of the households and the underlying reason for doing so. For this purpose, five households with various household members' demographic backgrounds are chosen. To elicit information for this study, the households are visited several times. The main interviewees are the women (mothers/wife) who are the key financial managers of the households. Sometimes the interviews were carried-out at the women's workplaces. The interview sessions were carried-out in an informal conversational approach. The study location is Mukim Laka Temin, Kubang Pasu District. Brief demographic background of each household is as follows (Table 1):

Table 1: Demographic Background of the Respondents

\begin{tabular}{|c|c|c|c|c|c|}
\hline Res. & $\begin{array}{l}\text { No. of household } \\
\text { members (age) }\end{array}$ & Employment & $\begin{array}{c}\text { No. of } \\
\text { working } \\
\text { members }\end{array}$ & $\begin{array}{l}\text { No. of } \\
\text { School age } \\
\text { children }\end{array}$ & Others (age) \\
\hline 1 & $\begin{array}{l}\text { Father (65) } \\
\text { Mother (62) } \\
\text { Sons (16, } 23 \text { and 26) } \\
\text { Grandson (8) }\end{array}$ & $\begin{array}{l}\text { Cleaner (mother) } \\
\text { Security guard (son) } \\
\text { Cleaner (son) }\end{array}$ & 3 & 2 & $\begin{array}{l}\text { Father is unable to work } \\
\text { due to previous injury. } \\
\text { A daughter studying at a } \\
\text { University (23) }\end{array}$ \\
\hline 2 & $\begin{array}{l}\text { Father (66) } \\
\text { Mother (60) } \\
\text { Daughters (22 and 24) } \\
\text { Sons (16 and 18) }\end{array}$ & $\begin{array}{l}\text { Labourer (father) } \\
\text { Assistant cook (daughter -22) } \\
\text { Sales girl (daughter-24) }\end{array}$ & 4 & 1 & $\begin{array}{l}\text { Father has heart problem } \\
\text { and therefore, unable to } \\
\text { work hard. } \\
\text { Son (18) is still } \\
\text { unemployed. }\end{array}$ \\
\hline 3 & $\begin{array}{l}\text { Father (47) } \\
\text { Mother (45) } \\
\text { Grandmother (80) } \\
\text { Daughters (12 and 14) } \\
\text { Son (8) }\end{array}$ & $\begin{array}{l}\text { Security guard (father) } \\
\text { Cleaner (mother) }\end{array}$ & 2 & 3 & $\begin{array}{l}\text { Grandmother is not very } \\
\text { well and need attention }\end{array}$ \\
\hline 4 & $\begin{array}{l}\text { Father (50) } \\
\text { Mother (47) } \\
\text { Sons (14 and 16) } \\
\end{array}$ & Tailor (Mother) & 1 & 2 & $\begin{array}{l}\text { Father is paralyze (half } \\
\text { paralyze) }\end{array}$ \\
\hline 5 & $\begin{array}{l}\text { Mother (38) } \\
\text { Sons (16-10) } \\
\text { Daughters (8 and 13) }\end{array}$ & Rubber Tapper (mother) & 1 & 3 & $\begin{array}{l}\text { Father (41) is working as } \\
\text { contract worker } \\
\text { (building construction) } \\
\text { in Singapore. } \\
\text { Son (16) is not interested } \\
\text { to attend school and } \\
\text { unemployed. }\end{array}$ \\
\hline
\end{tabular}




\section{FINDINGS AND ANALYSIS}

\subsection{Managing Households' Expenditure}

Table 2 shows the expenditure patterns and priorities of the households' expenditures of the respondents.

Table 2 has shown that the top priority of each poor household's expenditure is rice as the staple food for Malaysian. Most respondents agree that they have to ensure that supply of rice for the households' meals is available at all time. However, there are occasions where they have to get the rice in advance and pay later due to shortage of budget. There are shops that are willing to provide that form of service for the poor. They call as 555 book (buku 555). Most of the respondents bring their own food to work. This will save them a lot of money. However, the husbands prefer to buy lunch from food stalls. Their children are given daily allowances to school.

The second priority for all respondents is payment for utility bills. These include water and electricity. They really want to make sure that the supplies are not interrupted. If not, they have to pay the reconnection services which is to them is quite costly. Patrol/fuel for motorcycle is very important portion of poor households' budget in this study. Motorcycle is their main mode of transportation to go work, to send and fetch their children from school and for other activities. Two households put expenditure for husbands' medicine as the third priority. This is not a regular case as the husbands' medicines are supplied by public hospitals. The expenditure will incurred when there is a shortage of supplies of medicines in public hospitals.

Other food includes canned sardines, anchovies, dried fish, sugar, coffee, tea, salt etc. These things are purchased only necessary and only when there is surplus of money after the priorities have been budgeted. Fresh chicken and seafood will be purchased when they can afford to do so.

Expenditure for children's education constitutes a large portion of poor households' expenditure. There are a lot of activities to be attended by their children at schools. The children have to spend more time at school and they need extra allowance for their lunch. There are times where they have to take their children home for lunch and send back to the school for the extra-curricular activities to save money.

\subsection{Households' Strategies to Secure Enough Income to Sustain the Households' Basic Needs}

To secure enough income to sustain households' expenditure to cover the households' basic needs, respondent 1 and 3 do extra works during weekends. They do cleaning work 


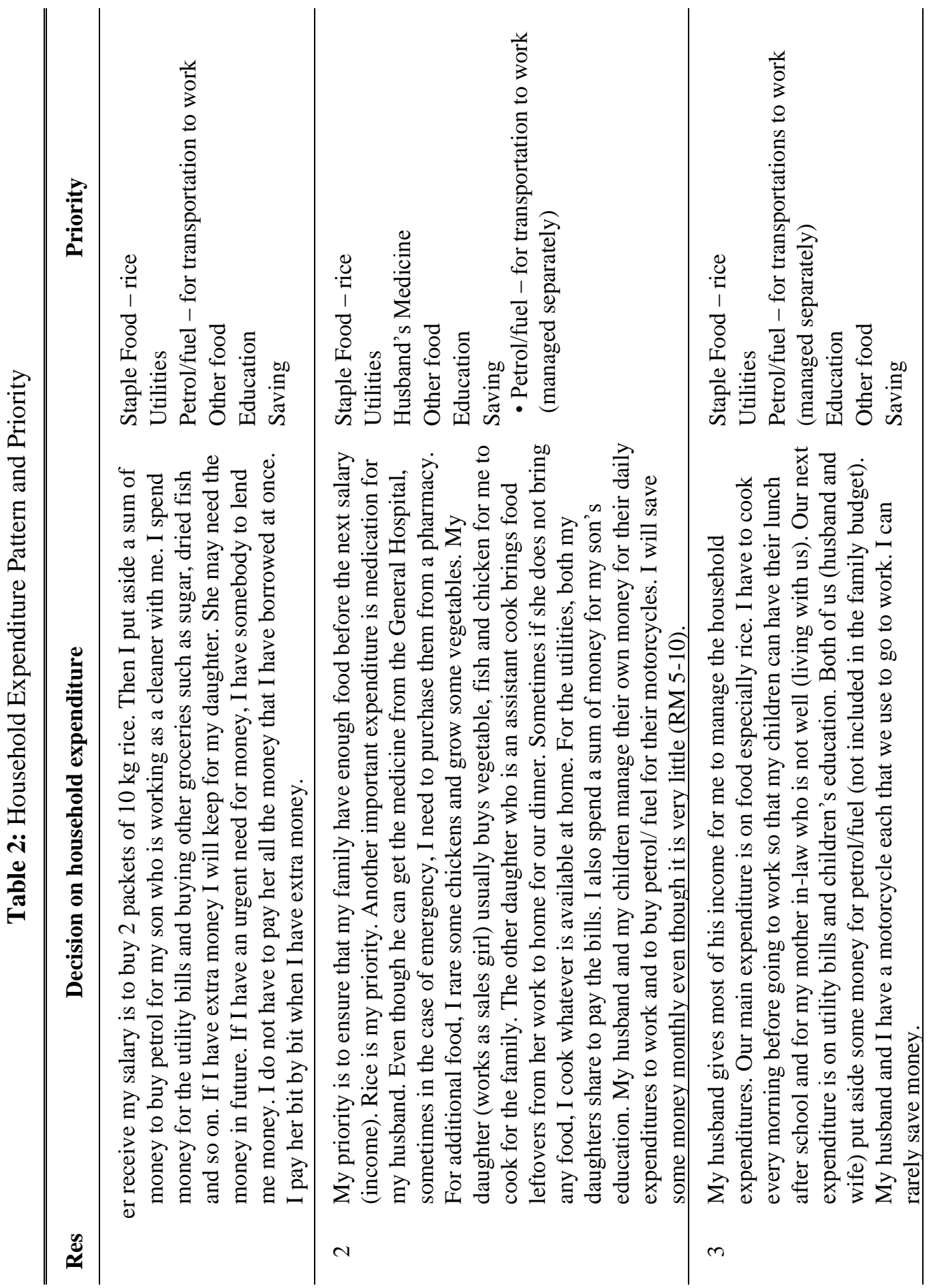




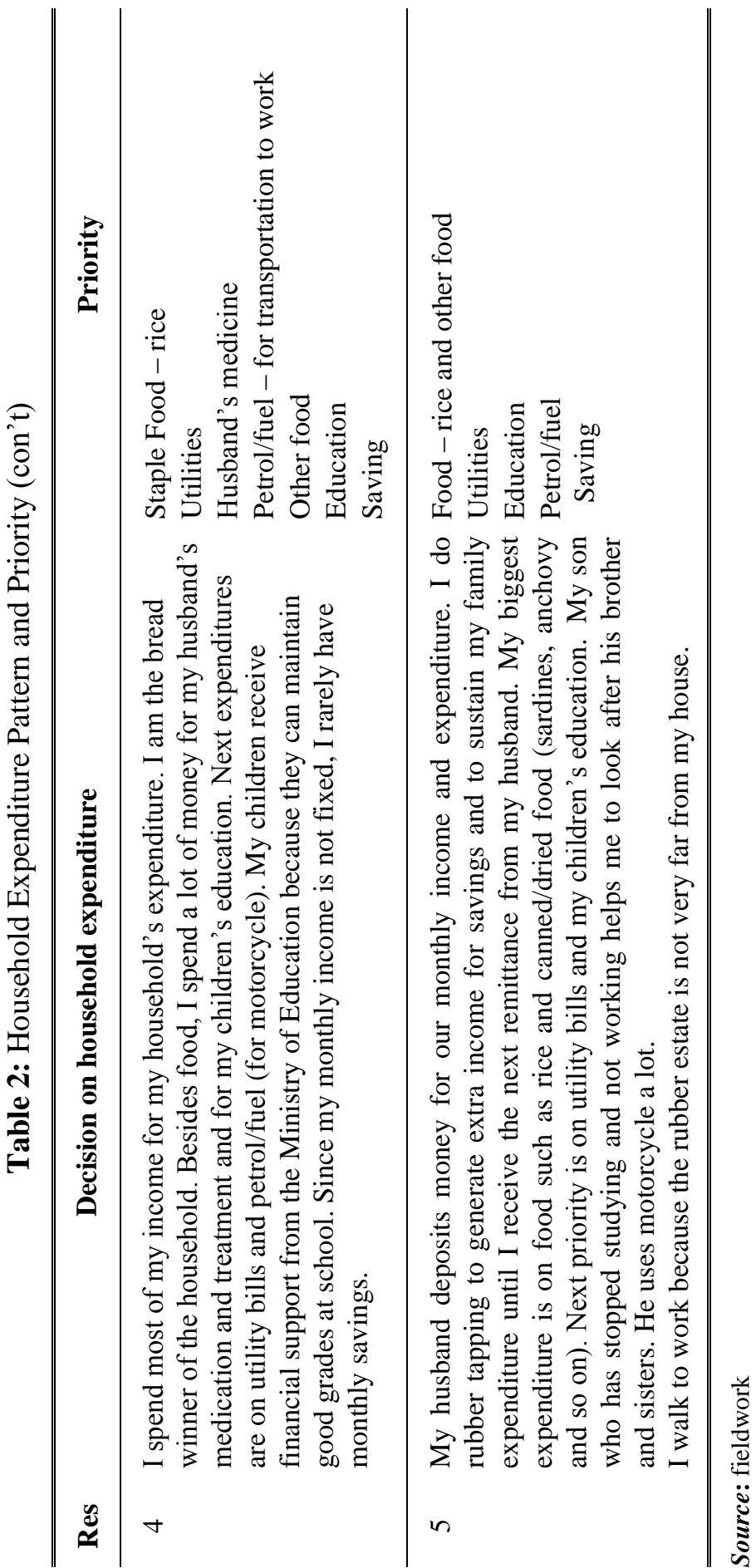


at several houses on almost every Friday. The income is used for saving for future needs or to spend for immediate needs. Respondent 2 prepares nasi lemak in the morning to be sold at food stalls nearby her house. Respondent 5 receives monthly remittance from her husband who is working in Singapore. For her, she has to make sure that she has saved some money for any emergency expenditure until she receives the next remittance from her husband. At the same time she works as a rubber tapper to generate extra income for her households. The end of a month and an early month are critical times for most households.

Therefore, even though they do not have cash in hands, they need to make sure that there is enough rice for the households' meals and petrol (motorcycle) to go to work before they receive the next salary. Respondent 4 is unable to have extra work because she has to spend her weekends to do housework as her husband is paralyzed. Since her income is not fixed, she has to stretch any extra income for savings. The highest income received is within three months before the Muslim Celebration Month (Hari Raya). The income is saved for the whole year's expenditure.

Besides doing extra work to sustain expenditure for households' basic needs, most of the households receive various sources of financial aids as shown in table 3.

Table 3: Other Source of Income

\begin{tabular}{cccccccc}
\hline \hline Res & Zakat & $\begin{array}{c}\text { Welfare } \\
\text { Dept. }\end{array}$ & $*$ BRIM & $\begin{array}{c}\text { Personal } \\
\text { Donation }\end{array}$ & $\begin{array}{c}\text { Educational } \\
\text { assistance }\end{array}$ & Remittance & *Others \\
\hline $\mathbf{1}$ & $/$ & $/$ & $/$ & $/$ & $/$ & & $/$ \\
$\mathbf{2}$ & $I$ & $I$ & $/$ & & $/$ & $/$ & $/$ \\
$\mathbf{3}$ & $I$ & $I$ & $/$ & $/$ & $/$ & $/$ & $/$ \\
$\mathbf{4}$ & $/$ & $I$ & $/$ & $/$ & $/$ & $/$ \\
$\mathbf{5}$ & & & $/$ & & $/$ & $/$ & $/$ \\
\hline \hline
\end{tabular}

Source: fieldwork

Notes: *BR1M - 1Malaysia People's Aid; *Others include: donation by individuals or groups during special occasions such as during Muslim Fasting Month (Ramadhan) and Raya Celebration (Eidul Azhar and Eidul Fitr)

The above findings show that one household may have a different set of basic needs from another household. However, the poor are left to deal with the basic needs that would support them to survive their everyday working activities and to support their children's education. This study demonstrates that the strategies adopted by poor households are to secure enough income to sustain the households' basic needs by doing extra works, selling food and savings. From the strategies, the study identifies the potential income generating activities that may provide opportunities for respondents to improve their socio-economic status are as follows: 
Table 4: Suggested Opportunities for Better Incomes based on Existing Strategies

\begin{tabular}{|c|c|c|}
\hline Respondent & Existing Strategy & Opportunity (suggestion) \\
\hline 1 and 3 & Extra work - cleaning jobs & $\begin{array}{l}\text { The house-to-house cleaning job is a very } \\
\text { profitable business. At the moment, the study area } \\
\text { are supplied with cleaners form Indonesia } \\
\text { employed by several Chinese proprietors. The } \\
\text { study area consists of many households with both } \\
\text { husbands and wives working at semi-professional } \\
\text { and professional levels. However, the locals } \\
\text { prefer Indonesian cleaners because they able to } \\
\text { provide a high standard cleaning work. }\end{array}$ \\
\hline 2 & Sell nasi lemak & $\begin{array}{l}\text { There are so many nasi lemak stalls around the } \\
\text { study area and yet the stall can survive due to } \\
\text { enough demand in the area. Since the respondent } \\
\text { does not have any job, it is worthwhile if she can } \\
\text { open her own nasi lemak stalls. Her daughter who } \\
\text { works as assistant cook can help her in this case. }\end{array}$ \\
\hline 4 & Tailoring work & $\begin{array}{l}\text { The demand for dress making is available all year } \\
\text { round and the demand increases dramatically } \\
\text { during the festive season and wedding season. } \\
\text { However, due to working alone, the respondents } \\
\text { unable to accept all the clothes send to her by her } \\
\text { customers. As a result she loses some of her } \\
\text { customers to the new tailors. The suggestion is } \\
\text { that she can hire more people working with her } \\
\text { provided she can purchase modern and up-to-date } \\
\text { sewing machines. }\end{array}$ \\
\hline
\end{tabular}

Source: Analysis of findings

The above suggestions can only be realized if the respondents are made aware of the opportunities (table 4). At present, the study finds that most of them do not realize the opportunities since they are focusing on the survival of the households' expenditure to cover the households' basic needs. In addition, even if the respondents realize the opportunities, they do not have the courage to take risk due to limited capitals and knowledge/ skills in business and the feeling that if they do not success, their households' welfare will be affected. Therefore, there should be a mechanism to assist the poor to proceed with economic activities that they are familiar with to enhance the households' incomes and their socio-economic status.

In Malaysia, there are various government and non-government agencies offer financial and equipment assistance for this purpose. However, due to certain limitations, the services do not reach some of the poor households. Therefore, further study should be carried-out to find-out the prevailing limitations within the agencies and to offer solutions for the limitations. 


\section{CONCLUSION}

This study discovers the expenditure of each poor household understudied is managed by a woman and each household has its own unique livelihoods strategy. The strategy is based on the type of jobs of the household members and the sources of incomes of a household members, the demographic background of the members and spending arrangements of the income generating household members. The study also discovers that all household prioritize the expenditure, generally food as the main priority, followed by utility bills, transportation cost to work, education and others. It is also discovered that most of the households constantly receive financial support from various sources such as government agencies and individuals in terms of zakat and donation.

The study also provides suggestions on opportunities for poor households' to improve their socio-economic status by upgrading their existing income generating activities to sustain their households' expenditures. However, these suggestions can only be realized if they are assisted with proper financial assistance and skill/ management trainings by various government and non-governmental poverty alleviation agencies.

\section{ACKNOWLEDGMENT}

On behalf of the research team, I would like to take this opportunity to express our gratitude especially to our respondents for willingly to take part in the interview sessions.

\section{REFERENCES}

Department of Census and Statistics. (2008). Poverty indicators: Household income and expenditure survey - 2006/07. Sri Lanka: Ministry of Finance and Planning, Department of Census and Statistics.

Drakakis-Smith, D. (1990). Concept of development. In D. Dwyer (Eds.), Southeast Asian development and change (pp. 48-77). New York: Longman Scientific and Technical.

Ellis, F. (1999). Rural livelihoods diversity in developing countries: Evidence and policy implications. Natural Resource Perspectives. Overseas Development Institute (ODI) No. 40.

Hossain, S. (2005). Poverty, household strategies and coping with urban life: Examining 'livelihood framework' in Dhaka City, Bangladesh. Bangladesh e-Journal of Sociology, 2(1), 1-8.

Jaiyebo, O. (2003). Women and household sustenance: changing livelihoods and survival strategies in the peri-urban areas of Ibadan. Environment \& Urbanization, 15(1), 111-120. 
Lewis, M. A (1981). Sectoral aspect of basic human needs approach: The linkages among population, nutrition and health. In Liepzinger, D.M (Eds.), Basic needs and development (pp. 29-106). Cambridge: Oelgeschlager, Gunn \& Hain Puclisher, Inc.

Mabogunjie, A. L. (1980). The development process: A spatial perspective. London: Hutchinson.

Oluwatayo, I. B. (2009). Poverty and income diversification among households in rural Nigeria: A gender analysis of livelihood patterns. A Paper Presented at The 2nd Instituto de Estudos Sociais e Económicos (IESE) Conference on 'Dynamics of Poverty and Patterns of Economic Accumulation in Mozambique', Maputo, Mozambique on 22-23 April 2009.

Peet, R., \& Hartwick, E. (1999). Theories of development. New York: Guilford Press.

Streeteen, P. (1981). First things first: Meeting basic human needs in developing countries. New York: Oxford University Press for the World Bank.

World Development Indicators. (2008). Poverty data: A supplement to world development indicators. Washington D.C: World Bank. 